\title{
STUDY OF AGRICULTURAL MATERIAL FREQUENCY RESPONSE IN ORDER TO ENSURE SAFETY OF TECHNOLOGIES USING SUPER HIGH FREQUENCIES
}

\author{
Elena Logacheva, Valery Zhdanov, Alexander Ivashina, Viktor Yarosh \\ Stavropol State Agrarian University, Russia \\ elena.logacheva2010@yandex.ru, valery@yandex.ru, \\ av_ivashina49@mail.ru,yarviktor@yandex.ru
}

\begin{abstract}
The article raises the problem of the safe implementation of new technologies using super high frequency electromagnetic fields. Growing global population requires more food production. Traditional crop cultivation technologies do not solve this problem. Modern agricultural production has been undergoing qualitative changes. New technologies using various electro physical factors have often been proposed to introduce in recent decades. One of these proposals is the use of super high frequency electromagnetic fields. Technologies are recommended for implementation, but implementation in real agriculture is not observed. The reason is that safe working conditions for the person managing this production have not been developed. The operation of a SHF installation cannot be narrowed down only to compliance with the rules for maintenance of electrical equipment. The proposed technologies require additions to the existing labor safety requirements. To this end, a hazard assessment of agricultural SHF technologies has been carried out. The study has been carried out in two directions: energy flux density at the workplace of the operator serving the installation for pre-sowing seed treatment; reflection coefficients of various agricultural materials. The analysis of the proposed SHF technologies has made it possible to present the SHF technologies classification, which has shown that the most dangerous option with an open radiating device is proposed for use in agriculture. The established frequency dependences of various agricultural materials at different sample moisture have shown a significant decrease in reflection coefficients at the lowest moisture. Therefore, from a safety standpoint, it is most preferable to process materials with a SHF electromagnetic field in combination with drying.
\end{abstract}

Keywords: labor safety, electromagnetic fields,super high frequency range, safe working conditions.

\section{Introduction}

The rapid population growth of the planet constantly requires an increase in food production. According to the United Nations forecasts, the world's population will have reached 9 billion people by 2050. The ever-growing demand for food is forcing the transformation of existing agriculture. At the moment, for successfully competing agricultural production, the usual resources, namely, land and water, are no longer enough. Efficient production implies more products produced using less resources, in other words new technologies are required.

An acute shortage of energy resources simultaneously with the inevitability of the emergence of new technologies entail serious qualitative changes in the use of electric energy. The proportion of electricity spent on thermal processes should be constantly reduced. In this regard, advanced technologies are being developed using electromagnetic fields of various frequencies. It is proposed to use SHF energy (super high frequency) in crop production for processing seeds of various crops before sowing, for weed control, for disinfecting greenhouse soil, for drying tea and medicinal herbs, in animal husbandry - for treating animals, stimulating milk flow, etc. It is possible to use SHF heating in the processing of agricultural products [1].

Technologically proposed methods are well developed. The question of safe work of people serving the production lines remains unexplored. The operation of a SHF installation cannot be narrowed down only to compliance with electrical safety rules. Compared to traditional technological heating equipment, SHF installations require additional knowledge and skills from personnel.

The state policy of Russia in the field of labor safety is determined by the basic principle of "recognition and ensuring the priority of the life and health of workers in relation to the results of production activities of the enterprise" [2]. It establishes the right of each person to have a "workplace protected from harmful or hazardous production factors that could cause work injury, occupational disease or a decrease in working capacity". Moreover, "the development and production of capital goods, the introduction of technologies that do not meet the requirements for labor safety, is not allowed." 


\section{Materials and methods}

The purpose of the study is to assess the danger of agricultural SHF technologies and develop measures to reduce it.

Electromagnetic waves were predicted by Maxwell in 1873 and experimentally discovered by Hertz in 1888. In 1926 V.I. Vernadsky wrote: "Around us, in ourselves, here, there and everywhere, without interruption, forever alternating, coinciding and colliding, is radiation of a different wave... We are beginning to recognize its diversity, to understand the fragmentary and incomplete nature of our ideas about the world of radiation that surrounds us and penetrates us in the biosphere, about its main significance in the processes surrounding us."

Living organisms have been exposed to electromagnetic waves throughout their existence. Sources of electromagnetic radiation are all cosmic bodies, primarily the Sun, and electrical processes occurring in the atmosphere. A huge impact on living organisms has static and magnetic field of the Earth.

In turn, all living objects are sources of electromagnetic waves in a wide range of frequencies, since any living organism consists of many cells, each of which contains atoms, molecules, charged particles.

Scientific progress has led to the widespread use in practice of a wide variety of wave processes. Man has created and has been developing a powerful industry. Everyday life is "saturated with electricity". A huge number of devices and gadgets come into general use. Radio broadcasting, television, radio navigation are all perceived as simple and obvious phenomena.

That is why people are increasingly asking questions of safe existence, the search for a compromise between the comfort of modern life and the need to preserve the natural "electromagnetic background".

The object of the study is SHF processes and equipment used in agricultural production, namely: energy flux density at the workplace of the operator serving the installation for pre-sowing seed treatment; reflection coefficients of various agricultural materials.

Experimental studies were carried out in the late 90s in the agricultural company "Leto" of the Leningrad Region, the Russian Navy Research Institute, at the Department of Labor Safety of the St. Petersburg State Agrarian University. The work has been resumed and has been continuing at the Electrical Power Faculty of the Stavropol State Agrarian University.

Dielectric heating is based on the displacement of charges and molecules associated with them, when a substance is exposed to an alternating electromagnetic field. Maxwell's theory presents the electromagnetic field as an inextricable interaction of two components - electrical $E\left(\mathrm{~V} \cdot \mathrm{m}^{-1}\right)$ and magnetic $H\left(\mathrm{~A} \cdot \mathrm{m}^{-1}\right)$. That is, an electromagnetic wave can be represented as a three-dimensional model, where two plane monochromatic waves of the same frequency, linearly polarized in mutually perpendicular planes, propagate in one direction [3-6].

In the technological process it is necessary to take into account the energy properties of an electromagnetic wave. The energy that a wave carries per unit of time through a unit of surface area located perpendicular to the direction of wave propagation is important for the developers. Making it onto the interface between two working substances, part of the electromagnetic wave is reflected, and part, being refracted, passes into the second working substance. The ratio of the intensities of the reflected and incident waves is called the reflection coefficient. It is possible to have both: the full reflection of the wave and the complete passage of the wave. The type of wave is largely determined by the design of the elements of the SHF installation [6; 7].

To create safe working conditions for the person managing this technological process, not only the energy properties of the electromagnetic field are important, but also its configuration [8;9]. Analysis of the high-frequency equipment of the proposed technologies has been carried out according to the following classification criteria $[4 ; 5 ; 10 ; 11]$.

Firstly, the SHF technology can be classified by the power of the SHF generator.

Secondly, the degree of danger depends on the stationary or mobile design of the SHF installation. 
Thirdly, the classification can be carried out according to the design of the energy input device, which can be such as: the open end of the waveguide, a horn, a truncated horn, a truncated waveguide, a gap in a metal screen, etc. (Fig. 1).

Fourthly, when assessing the degree of danger of SHF technology, it is important whether there is a direct contact of the energy input device with the material being processed, or is it processed through an air layer (Fig. 2) [4; 5].

a)

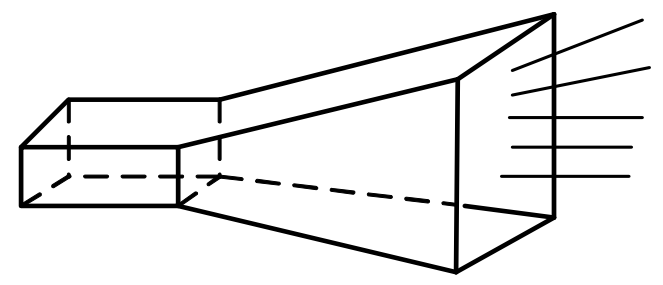

b)

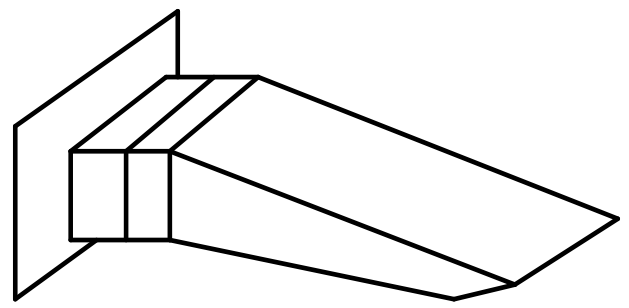

Fig. 1. Energy input device: a - pyramidal horn radiator; $b$ - truncated wave guide radiator

a)

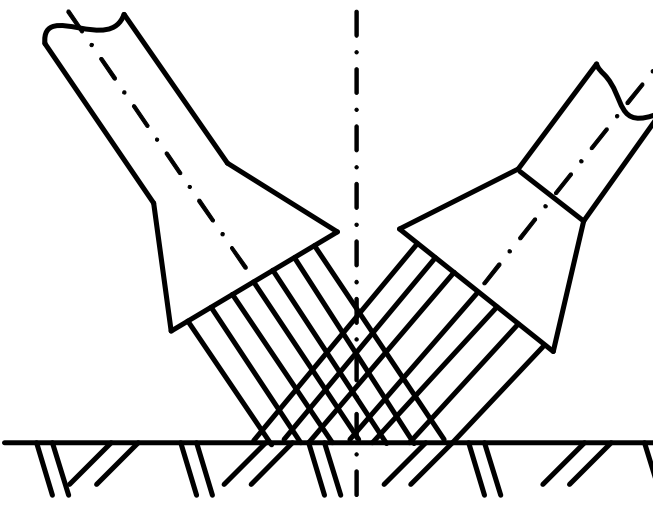

b)

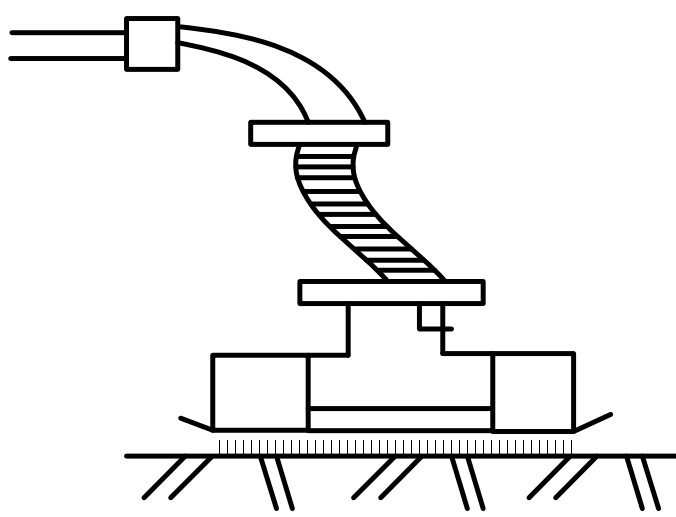

Fig. 2. Presence or absence of air gap between the energy input device and the processed material: $a$ - air layer; $b$ - direct contact

SHF installations for potential hazard posed to maintenance personnel are classified as follows (Fig. 3).

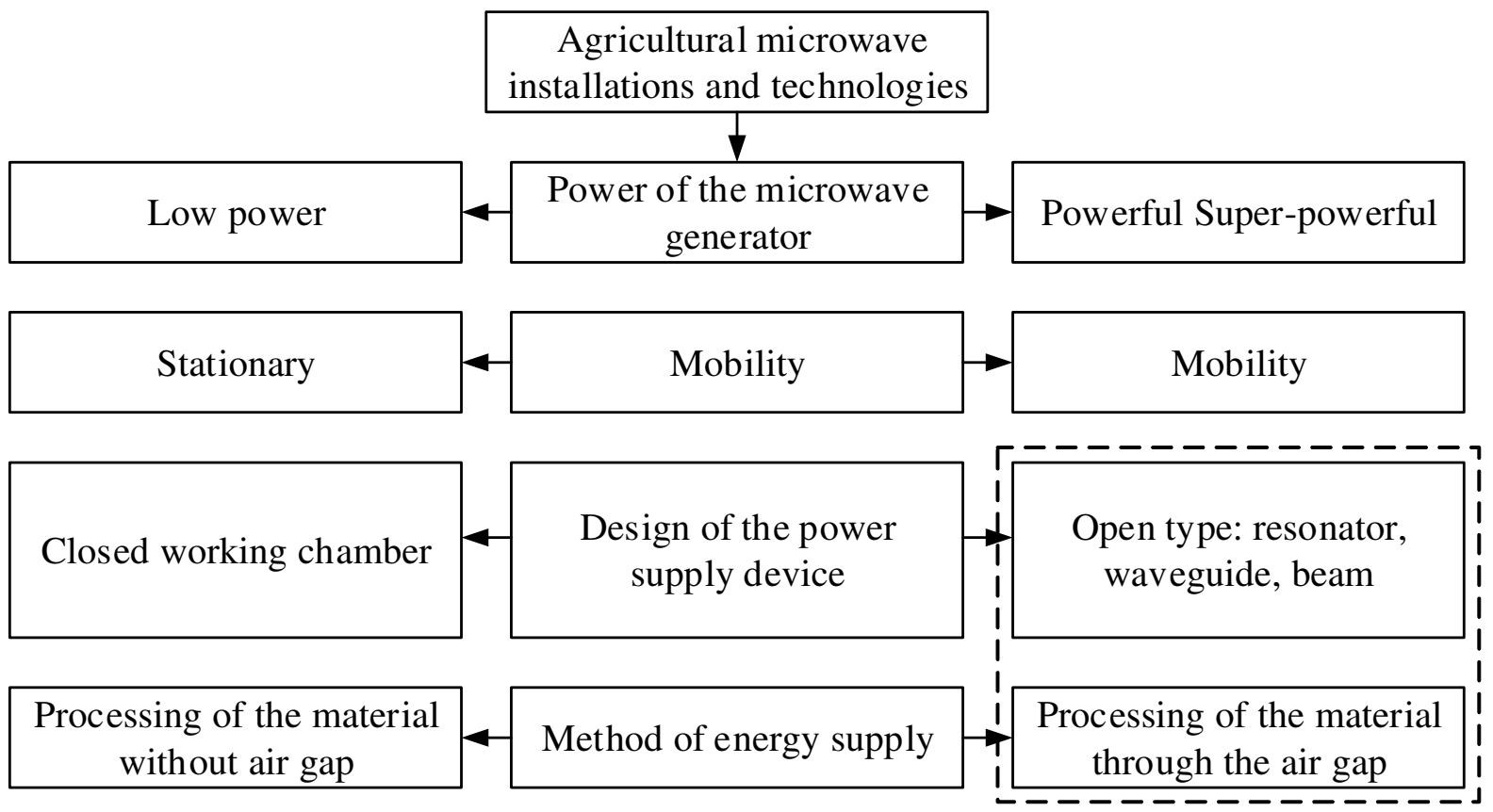

Fig. 3. Classification of SHF installations 
The study program. It is obvious that only the simplest installations can be an example for considering only one classification feature $[12 ; 13]$. In order to experimentally verify the validity of the presented classification, experimental studies have been carried out according to the following program:

- study of the parameters of the electromagnetic field of super high frequency (SHF EMF);

- obtaining frequency characteristics of the standing-wave ratio (SWR) of various agricultural materials;

- obtaining the values of the reflection coefficients $\mathrm{G}$ of various agricultural materials at different moisture of the sample.

Materials, methods and objects of the study. The study of the frequency characteristics of agricultural materials has been carried out on a panoramic SWR meter P2-42, designed for panoramic display on the oscilloscope screen and measuring the SWR values. The operating frequency range is from 2.29 to $6.14 \mathrm{GHz}$, the waveguide section is $48 \times 24 \mathrm{~mm}$. The structural diagram of the SWR measurement is presented in Fig. 4 [4; 5].

The basis of the SWR meter is the work of the reflectometer. The reflectometer detects the signals of the wave which is incident from the generator and the wave is reflected from the measured object. Two directional detectors connected in series carry out separate signal extraction.

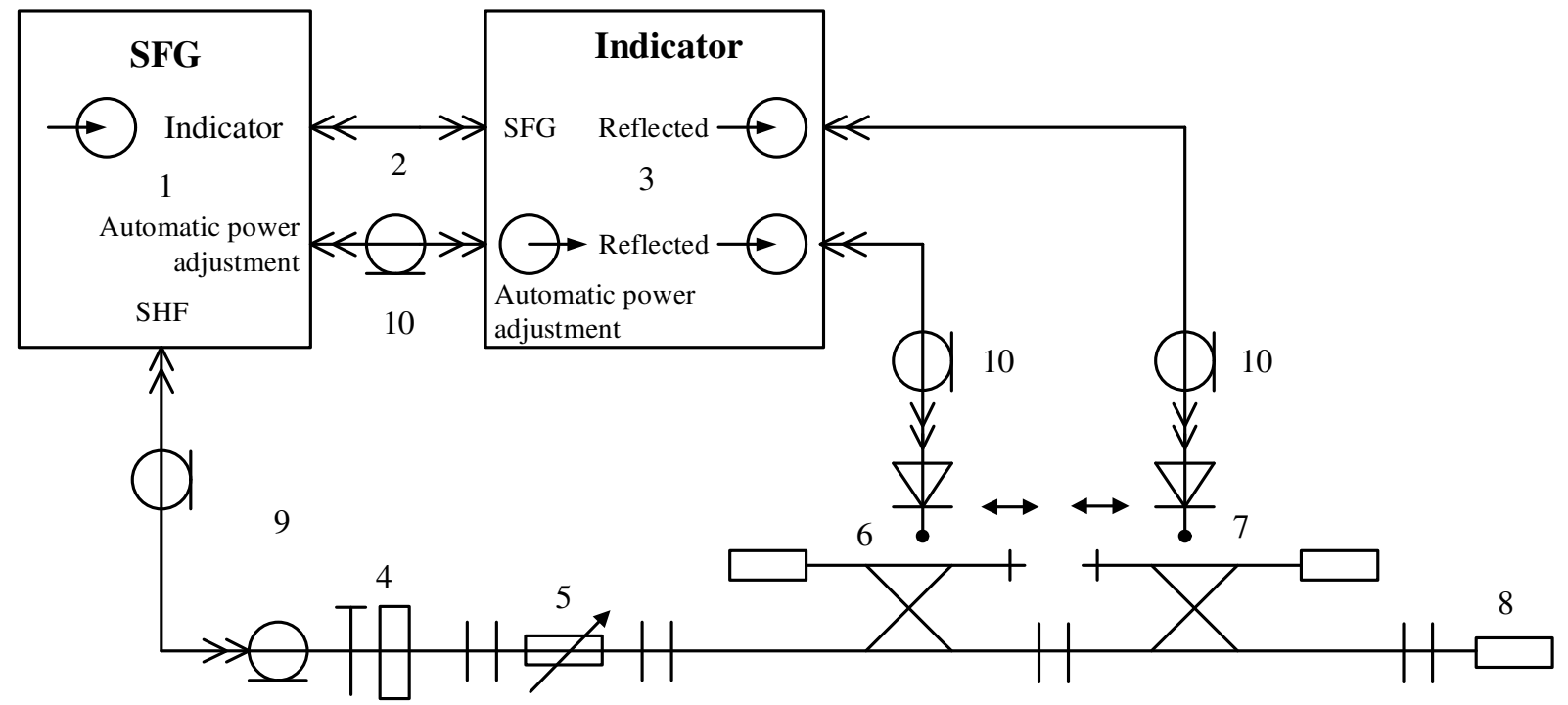

Fig. 4. Structural SWR measurement circuit: 1 - swept frequency generator; 2 - cable; 3 - indicator Я2P-67; 4 - waveguide-to-coaxial adapter; 5 - attenuator; 6 - directional detector

"incident"; 7 - directional detector "reflected"; 8 - measured object; 9, 10 - connection cable

For each sample (seeds of wheat, barley, soy, corn, pea, tea, chicory, dried fruit, etc.) moisture has been varied $(10,20,30 \%)$ and the SWR in units of SWR has been determined over the entire frequency range with a step of $500 \mathrm{MHz}$, according to well-known formulas, the reflection coefficient $G$ has been calculated [4-6].

$$
\operatorname{SWR}=\frac{1+|G|^{2}}{1-|G|^{2}} .
$$

\section{Results and discussion}

As a result of the experimental studies, the dependences of the SWR of a number of agricultural materials have been obtained for various moisture samples in the frequency range from 2290 to $6140 \mathrm{MHz}$ (Figure 5 and Table 1).

The study of the processes of electromagnetic field formation is necessary to determine safe working conditions for people. The results of the study can be used in the main areas: in the normalization, that is, the determination of the parameters of the acting factor and its maximum 
permissible values; in the control of an existing hazard; in the development of protective measures [4-5].
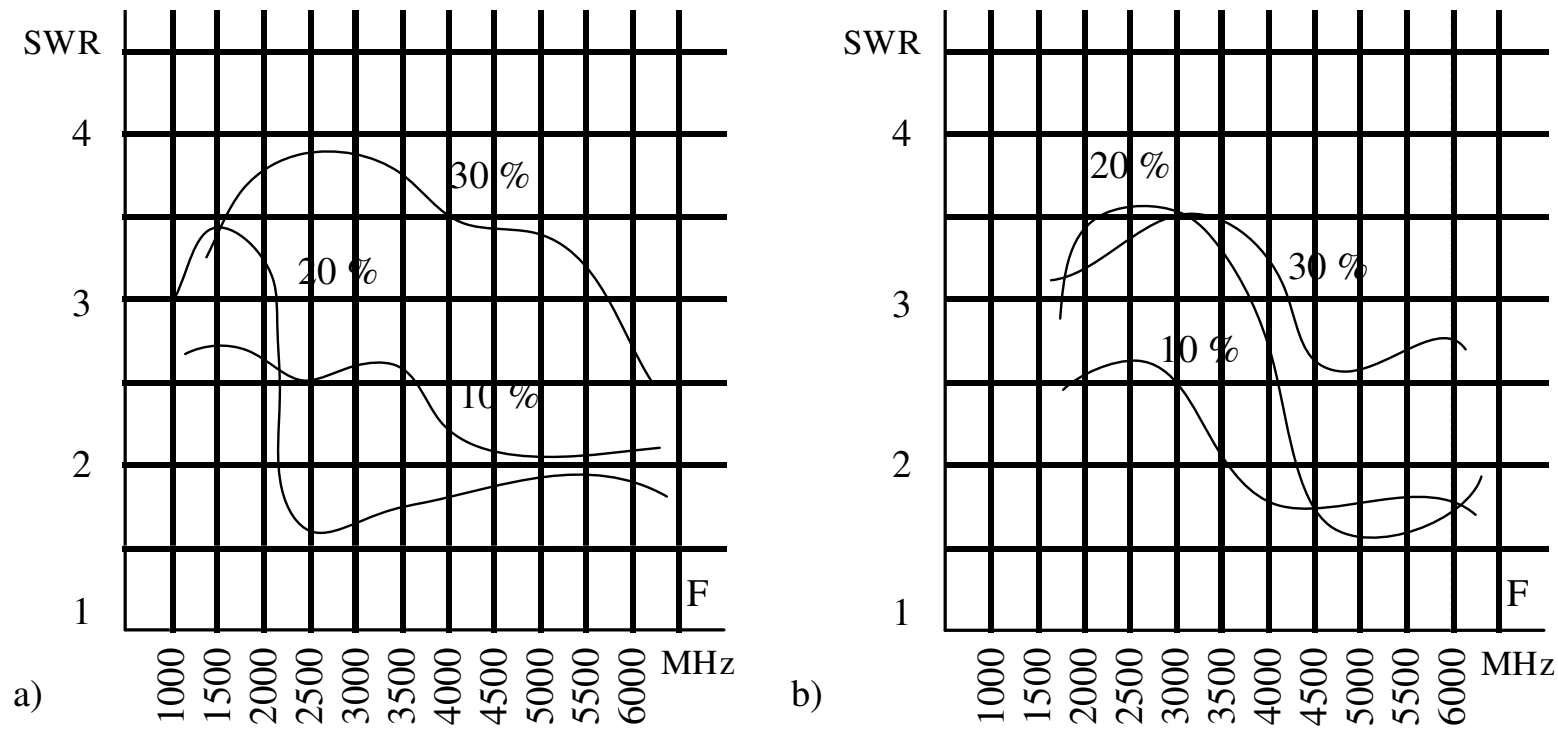

Fig. 5. SWRinfluence curves of agricultural materials samples: $a$ - corn; $b$ - pea

Coefficients of standing wave SWR and reflection G of sunflower seeds,

Table 1 measured in panoramic mode

\begin{tabular}{|c|c|c|c|c|}
\hline \multirow{2}{*}{$\begin{array}{c}\text { Frequency, } \\
\text { MHz }\end{array}$} & Test & \multicolumn{3}{|c|}{ Sample moisture } \\
\cline { 2 - 5 } characteristics & $\mathbf{1 0} \%$ & $\mathbf{2 0} \%$ & $\mathbf{3 0} \%$ \\
\hline \multirow{2}{*}{2000} & $\mathrm{SWR}$ & 2.3 & 3.2 & 4.8 \\
\cline { 2 - 5 } & $\mathrm{G}$ & 0.6276 & 0.7237 & 0.8094 \\
\hline \multirow{2}{*}{2500} & $\mathrm{SWR}$ & 2.4 & 2.9 & 4.7 \\
\cline { 2 - 5 } & $\mathrm{G}$ & 0.6416 & 0.6979 & 0.8056 \\
\hline \multirow{2}{*}{3000} & $\mathrm{SWR}$ & 1.3 & 2.8 & 3.1 \\
\cline { 2 - 5 } & $\mathrm{G}$ & 0.3611 & 0.6882 & 0.7156 \\
\hline \multirow{2}{*}{3500} & $\mathrm{SWR}$ & 2 & 3 & 2.8 \\
\cline { 2 - 5 } & $\mathrm{G}$ & 0.5773 & 0.7071 & 0.6882 \\
\hline \multirow{2}{*}{4000} & $\mathrm{SWR}$ & 2 & 3.25 & 2.75 \\
\cline { 2 - 5 } & $\mathrm{G}$ & 0.5773 & 0.7276 & 0.6831 \\
\hline \multirow{2}{*}{4500} & $\mathrm{SWR}$ & 1.6 & 3.35 & 2.8 \\
\cline { 2 - 5 } & $\mathrm{G}$ & 0.4803 & 0.735 & 0.6882 \\
\hline \multirow{2}{*}{5000} & $\mathrm{SWR}$ & 1.5 & 3 & 3.1 \\
\cline { 2 - 5 } & $\mathrm{G}$ & 0.4644 & 0.7071 & 0.7156 \\
\hline \multirow{2}{*}{5500} & $\mathrm{SWR}$ & 1.7 & 2.1 & 3.1 \\
\cline { 2 - 5 } & $\mathrm{G}$ & 0.5091 & 0.5956 & 0.7156 \\
\hline \multirow{2}{*}{6000} & $\mathrm{SWR}$ & 1.4 & 1.9 & 2.85 \\
\cline { 2 - 5 } & $\mathrm{G}$ & 0.4082 & 0.557 & 0.693 \\
\hline
\end{tabular}

\section{Conclusions}

1. The above classification of SHF technologies has shown that the most dangerous option with an open radiating device is proposed for use in agriculture.

2. The established frequency dependences of a large number of samples of various agricultural materials at different sample moisture have shown a significant decrease in reflection coefficients at the lowest moisture. Therefore, from a safety standpoint, the most preferred is the processing of materials by SHF EMF in combination with traditional drying. 
3. Experimental studies of the frequency characteristics of agricultural materials in the frequency range from $2290 \mathrm{MHz}$ to $6140 \mathrm{MHz}$ have shown that of the two frequencies allowed for use $(2450 \mathrm{MHz}, 5800 \mathrm{MHz}), 5800 \mathrm{MHz}$ is safer.

\section{References}

[1] Изаков Ф.Я. Основные направления научных исследований по применению сверхвысокочастотной энергии в сельском хозяйстве (The main directions of scientific research on the use of ultrahigh frequency energy in agriculture) Применение энергии высоких и сверхвысоких частот в технологических процессах с.-х. производства. Сборник научных трудов. Челябинск, 1983. pp. 5-9. (In Russian).

[2] Трудовой кодекс Российской Федерации от 30.12.2001 № 197-Ф3 (ред. от 01.04.2019). (In Russian).

[3] Логачева Е.А. Оценка опасности сельскохозяйственных СВЧ технологий и меры по ее снижению (Hazard assessment of agricultural microwave technologies and measures to reduce it): abstract of dis.... cand. tech. sciences: Saint-Petersburg, 1995. 17 p. (In Russian).

[4] Логачева Е.А., Жданов В.Г. Электромагнитная безопасность производственного оборудования (Electromagnetic safety of production equipment) Методы и технические средства повышения эффективности использования электрооборудования в промышленности и сельском хозяйстве: Сб. научных трудов по мат. 74 науч.-практ. конф. электроэнергетического факультета. - СтГАУ. Ставрополь, 2010. pp. 120-122.(In Russian).

[5] Логачева Е.А., Жданов В.Г. Так ли безопасны экологически чистые СВЧ-установки? (Are environmentally friendly microwave installations so safe?). Сельскиймеханизатор. 2012. № 5. pp. 26-27. (In Russian).

[6] Atanov I.V., Mastepanenko M.A., Ivashina A.V., Zhdanov V.G., Logacheva E.A., Avdeeva V.N. Seed treatment by pulsed electric field before sowing. Research Journal of Pharmaceutical, Biological and Chemical Sciences. 2016. vol. 7. № 6. pp. 1664-1671.

[7] Vendin S.V., Saenko Yu.V., Kitaeva O.V., Soloviev S.V., Kazakov K.V., Ulyantsev Yu.N. Results of experimental studies on using mwf electromagnetic field energy for pre-sowing treatment of grain crops. International Journal of Advanced Science and Technology, vol. 29 (3), 2020, pp. 3747-3763.

[8] Барышев М.Г., Васильев Н.С., Куликова Н.Н., Джимак С.С. Влияние низкочастотного электромагнитного поля на биологические системы (Low Frequency Electromagnetic Field Impact on Biological Systems), Южный научный центр РAH, Ростов-на-Дону (South Scientific Centre of Russian Science Academy, Rostov on Don), 2008. 288 p. (In Russian).

[9] Любомудров А.А. Основы безопасности при работе с источниками электромагнитных полей (Basics of safety in time of working with sources of electromagnetic fields), Институтбезопасноститруда, Москва (IBT Press, Moscow), 2011. 279 p. (In Russian).

[10] Guo W., Yang J., Zhu X., Wang S. Frequency, moisture, temperature, and density-dependent dielectric properties of wheat straw. Transactions of the ASABE, vol. 56, 2013, pp. 1069-1075.

[11] Kaatze U., Hübner C. Electromagnetic techniques for moisture content determination of materials. Measurement Science and Technology, vol. 21, 2010. 26 p. 082001.

[12]Lin J.C., Michaelson S.M. Biological effects and health implications of radiofrequency radiation. Springer US, 1987. $675 \mathrm{p}$.

[13] Nelson S.O., Trabelsi S. Factors influencing the dielectric properties of agricultural and food products. Journal of Microwave Power and Electromagnetic Energy, vol. 46, 2012. pp. 93-107. 